\title{
Prevalence and Risk Factor Analysis of Bovine Hemoplasma Infection by Direct PCR in Eastern Hokkaido, Japan
}

\author{
Michihito TAGAWA ${ }^{1,2)}$, Adrian P. YBANEZ ${ }^{1,2)}$, Kotaro MATSUMOTO') ${ }^{1}$, Naoaki YOKOYAMA ${ }^{3)}$ and \\ Hisashi INOKUMA ${ }^{1) *}$ \\ 1) Department of Clinical Veterinary Medicine, Obihiro University of Agriculture and Veterinary Medicine, Inada, Obihiro, Hokkaido, \\ 080-8555, Japan \\ 2)United Graduate School of Veterinary Sciences, Gifu University, Gifu 501-1193, Japan \\ 3) National Research Center for Protozoan Diseases, Obihiro University of Agriculture and Veterinary Medicine, Inada, Obihiro, \\ Hokkaido, 080-8555, Japan
}

(Received 15 March 2012/Accepted 28 April 2012/Published online in J-STAGE 22 May 2012)

ABSTRACT. The prevalence and risk factors of 2 bovine hemoplasma species-Mycoplasma wenyonii (Mw) and "Candidatus Mycoplasma haemobos" (CMh) - were examined by direct PCR using whole blood samples collected from 343 cattle in Eastern Hokkaido, Japan. The sensitivity of the direct PCR assay was 10-fold higher than the standard PCR assay, detecting 5 copies of bovine hemoplasma DNA per reaction. An epidemiological survey of sampling location, living conditions, age and bovine leukemia virus antibody was performed to assess infection risk factors. The prevalence rates were $38.5 \%$ for $\mathrm{Mw}$ and $39.1 \%$ for $\mathrm{CMh}$, respectively, with an overall prevalence rate of $64.7 \%$ for all bovine hemoplasma infections. Significant differences were found in sampling location, living conditions and age. Compared with pastured cattle, farmed cattle were significantly more susceptible to infection with total hemoplasma species $(P<0.001)$, and were particularly susceptible to $\mathrm{CMh}(P<0.001)$. Cattle that were $1-3$ years of age were more susceptible to infection with hemoplasma compared with other age groups. Bovine leukemia virus infection status was not significantly associated with hemoplasma infections. Blood examination revealed significantly lower RBC, Hb, and PCV levels, and a higher MCV in infected cattle than in noninfected cattle. KEY WORDS: bovine hemoplasma, direct PCR, Japan, risk factor.

doi: 10.1292/jvms.12-0118; J. Vet. Med. Sci. 74(9): 1171-1176, 2012

Hemotropic mycoplasmas, also known as hemoplasmas, are unculturable bacteria that cause infectious anemia in several mammalian species [19, 25]. Originally known as Haemobartonella and Eperythrozoon species, these organisms have been reclassified as genus Mycoplasma based on 16S rRNA sequences and morphologic similarities [21, 34]. In cattle (Bos taurus), 2 distinct species have been identified, namely, Mycoplasma wenyonii (Mw: formerly, Eperythrozoon wenyonii) [22] and a provisional species termed "Candidatus Mycoplasma haemobos" (CMh: synonym, "Candidatus M. haemobovis") [28]. First identified in 1934 in a splenectomized calf [1], Mw is widely distributed throughout the world [19]. On the other hand, CMh has only recently been identified in Switzerland, China and Japan [10, 26, 28]. Clinical signs of hemoplasma infection in cattle include anemia, transient fever, lymphadenopathy, anorexia, weight loss and decreased milk production. In most animals, however, the infection remains subclinical and chronic $[19,25]$. The routes of transmission are still uncharacterized, although mechanical and transplacental transmission routes have been suggested [11].

Diagnosis of hemoplasma infection is usually made

\footnotetext{
* Correspondence to: Inokuma, H., Department of Clinical Veterinary Medicine, Obihiro University of Agriculture and Veterinary Medicine, Inada, Obihiro, Hokkaido 080-8555, Japan.

e-mail: inokuma@obihiro.ac.jp

(C)2012 The Japanese Society of Veterinary Science
}

based on detection of bacterial pathogens on the erythrocyte surface or in plasma through microscopic examination of Giemsa-stained blood smears. However, the sensitivity and specificity of this method are low [17]. Recently, sensitive molecular techniques, such as conventional polymerase chain reaction (PCR) and real-time PCR, have been used to detect and diagnose hemoplasma infection in various mammalian species [19, 24, 27]. These methods have been used successfully in investigations of prevalence and risk factors of hemoplasma infection in dogs and cats. In particular, detailed analyses of risk factors revealed that place of domicile, living conditions, age, breed and retroviral infections were important risk factors of hemoplasma infection in dogs and cats $[6,15,23,32,34]$. Although these molecular methods have also been applied in cattle [18, 22, 28], only a few reports regarding epidemiological investigation of risk factors for bovine hemoplasma infections exist.

Recently, direct PCR assays for hemoparasites, such as Babesia gibsoni, and hemoplasma species using whole blood of dogs and cats have been developed to reduce time, cost and labor and to eliminate contamination risks [31, 33]. Moreover, direct PCR was also used in a large-scale epidemiological study for bovine mastitis caused by Mycoplasma infection as a faster, easier method of screening [9]. Therefore, it is thought that a direct PCR method can also detect bovine hemoplasma infections and is suitable for largescale investigation. However, the direct PCR approach has not been fully evaluated or applied to the investigation of 
bovine hemoplasma infections.

The present study aimed to evaluate direct PCR as an alternative method to standard PCR for detection of bovine hemoplasma infections and to apply this method to assess risk factors and the clinical significance of bovine hemoplasma infections.

\section{MATERIALS AND METHODS}

Samples: EDTA-anticoagulated blood samples were collected from 49 cattle (Bos taurus) from a pastureland in Kushiro District, Hokkaido, Japan, in June 2011. Standard PCR was performed with DNA extracted from $200 \mu l$ of whole blood using a QIAamp DNA Blood Mini Kit (QIAGEN, Hilden, Germany), which was then eluted with $200 \mu l$ of buffer $\mathrm{AE}$ and stored at $-30^{\circ} \mathrm{C}$ until use. The remainder of the blood samples was stored at $-30^{\circ} \mathrm{C}$ until use for direct PCR. An epidemiological survey was performed on a total of 343 EDTA-anticoagulated blood samples collected from cattle on 3 farms and 1 pastureland in Tokachi and Kushiro Districts, Hokkaido, Japan, in 2010 and 2011 (Table 1). The animals of group A were moved from the farm around the pastureland and divided amongst several areas of the pastureland. Half of the samples of group B was from newborn calves. The farms of group $\mathrm{C}$ and $\mathrm{D}$ were not very far apart. The group $\mathrm{C}$ animals were fed in a free stall barn; on the other hand, the aminals in group D were fed in a tie stall barn or in the meadows of the farm. Living conditions and age were recorded for risk factor analyses. Complete blood counts (CBC) were obtained for 291 of 343 samples. Blood samples were stored at $-30^{\circ} \mathrm{C}$ prior to analysis of hemoplasma infections.

Standard and direct PCR: Detection of hemoplasma infection in both standard and direct PCR was performed with 10 pmol of the primer pair F2 (5'-ACGAAAGTCTGATGGAGCAATA- $\left.3^{\prime}\right)$ and R2 (5'-ACGCCCAATAAATCCGRATAAT-3') [13]. These primers amplify 16S rRNA genes of most hemoplasma, including $M$. haemofelis, $M$. haemocanis, "Candidatus M. haemominutum", "Camdidatus M. haemopurvum", $M$. wenyonii and "Candidatus M. haemobos" $[13,28]$. The expected amplicons were $193 \mathrm{bp}$ for $\mathrm{Mw}$ and 170 bp for CMh, respectively [28]. A 20- $\mu l$ reaction mixture for standard DNA contained: $2.5 \mu l$ of $10 \mathrm{X}$ buffer, $2.5 \mu l$ of 2 $\mathrm{mM}$ dNTP, $1 \mu l$ of $50 \mathrm{mM} \mathrm{MgCl}_{2}, 0.75 \mathrm{U}$ of Taq polymerase (Invitrogen, Carlsbad, CA, U.S.A.), $0.1 \mu l$ of each primer, $11.35 \mu l$ of distilled water, and $0.5 \mu l$ of DNA template. The cycling conditions for standard PCR were as follows: initial denaturation at $95^{\circ} \mathrm{C}$ for $5 \mathrm{~min} ; 35$ cycles of denaturation at $95^{\circ} \mathrm{C}$ for $30 \mathrm{sec}$, annealing at $60^{\circ} \mathrm{C}$ for $30 \mathrm{sec}$ and extension at $72^{\circ} \mathrm{C}$ for $90 \mathrm{sec}$; and a final extension at $72^{\circ} \mathrm{C}$ for $5 \mathrm{~min}$. The primer pair CG218f (5'-CCATCTTCCAGGAGCGAGA-3') and CG694r (5'-GGAAGGCCATGCCAGTGAG C-3') was designed based on the glyceraldehyde 3-phosphate dehydrogenase $(G A P D H)$ gene (GenBank accession no. NM001034034) to amplify a 478-bp fragment as an internal control. The PCR cycling conditions for GAPDH were the same as those described for standard PCR.

Direct PCR was performed using whole blood in a $20-\mu l$
Table 1. Sample characteristics of each group

\begin{tabular}{llccc}
\hline \multirow{2}{*}{ Variable } & \multicolumn{4}{c}{ Group $^{\mathrm{a})}$} \\
\cline { 2 - 5 } & $\mathrm{A}(\mathrm{n}=91)$ & $\mathrm{B}(\mathrm{n}=46)$ & $\mathrm{C}(\mathrm{n}=150)$ & $\mathrm{D}(\mathrm{n}=56)$ \\
\hline District & Kushiro & Kushiro & Tokachi & Tokachi \\
Living condition & Pastureland & Farm & Farm & Farm \\
Breed & & & & \\
$\quad$ Holstein-Friesian & 91 & 30 & 150 & 56 \\
F1 $^{\mathrm{b})}$ & 0 & 16 & 0 & 0 \\
Gender & & & & \\
$\quad$ Female & 91 & 37 & 150 & 56 \\
$\quad$ Male & 0 & 9 & 0 & 0 \\
\hline
\end{tabular}

a) Group A: cattle pastured in Kushiro District. Group B: cattle fed in Kushiro District. Group C: cattle fed in a free stall barn in Tokachi District. Group D: cattle fed in a tie stall barn in Tokachi District. b) First filial generation: Holstein-Friesian and Japanese Black.

reaction mixture containing: $10 \mu l$ of $2 \mathrm{X}$ Ampdirect Plus ${ }^{\circledR}$ (Shimadzu, Japan), 0.5 U of NovaTaq ${ }^{\mathrm{TM}}$ Hot Start DNA Polymerase (Novagen, UK), $0.1 \mu l$ of each primer (same as for standard PCR), $7.4 \mu l$ of distilled water, and $0.5 \mu l$ of whole blood as a template. The cycling conditions for direct PCR were as follows: preheating at $80^{\circ} \mathrm{C}$ for $15 \mathrm{~min}$; initial denaturation at $95^{\circ} \mathrm{C}$ for $10 \mathrm{~min} ; 35$ cycles of denaturation at $94^{\circ} \mathrm{C}$ for $30 \mathrm{sec}$, annealing at $60^{\circ} \mathrm{C}$ for $30 \mathrm{sec}$ and extension at $72^{\circ} \mathrm{C}$ for $90 \mathrm{sec}$; and a final extension at $72^{\circ} \mathrm{C}$ for $7 \mathrm{~min}$. All amplicons were electrophoresed on a 2.0\% agarose gel in TBE buffer and visualized under UV light. Random samples from positive amplicons were purified using a QIAquick PCR Purification Kit (QIAGEN, Valencia, CA, U.S.A.) and analyzed by direct sequencing [28]. Nucleotide sequence results were checked against known sequences using the BLAST search program (http://www.ncbi.nlm.nih.gov/blast/ Blast.cgi).

A recombinant DNA plasmid $(439.4 n \mathrm{~g} / \mu l)$ was used as a PCR template to determine the sensitivity of each PCR method. A representative PCR amplicon was cloned into the TOPO TA Cloning Kit pCR 4-TOPO Vector (Invitrogen). Plasmid DNA was extracted from cultured E.coli using a Plasmid Mini Kit (QIAGEN). A plasmid solution containing $1.036 \times 10^{8} \mathrm{copies} / \mu l$ was prepared as a template for each PCR method. The plasmid solution was subjected to 10 -fold serial dilutions (from $10^{-1}$ to $10^{-8}$ ) using distilled water for standard PCR and normal bovine blood for direct PCR. PCR amplifications were performed as described previously. The last dilution yielding a positive result was assumed to be the limit of detection. The same examinations were carried out twice to assess reproducibility.

$B L V$ test: Bovine leukemia virus (BLV) was assessed for 206 cattle using agar gel immunodiffusion (AGID), which detects specific antibodies raised against BLV gp proteins (Hokuken, Kitasato Inst., Kitamoto, Japan). BLV test data were not available for all samples, since examination of BLV antibodies was conducted for other studies.

Statistical analysis: Statistical analysis was performed to assess potential risk factors. The following variables were compared using the chi-square test: sample origin, living 
conditions, age, and BLV status. Nonparametric statistical tests (Mann-Whitney $U$ test) were performed to analyze hematological findings. $P<0.05$ was considered statistically significant. Breed and gender were not included in the statistical analysis due to the presence of noticeable bias.

\section{RESULTS}

Sensitivity evaluation of the direct PCR assay: With direct PCR, CMh DNA was detected at a $10^{-7}$ dilution, with a detection limit of 5 copies/PCR (Fig. 1). With standard PCR, CMh DNA was detected at a $10^{-6}$ dilution, with a detection limit of 52 copies/PCR. These results were reproducible in both assays. In direct PCR, positive bands were detected in 35 of 49 samples (71.4\%), including 18 for Mw infection, 11 for $\mathrm{CMh}$ infection, and 6 for dual infection. In standard PCR, positive bands were detected in 33 of 49 (67.3\%) samples, including 17 for $\mathrm{Mw}$ infection, 11 for $\mathrm{CMh}$ infection, and 5 for dual infection. All standard-PCR-positive samples were positive in the direct PCR assay. In both PCR assays, GAP$D H$ was detected in all samples. Sequence analysis results of randomly selected positive amplicons from direct PCR were most closely related to Mw (HM538191) and CMh (EU367965), with percent identities of $99.33 \%$ and $99.21 \%$, respectively.

Epidemiological survey: All 343 samples were analyzed by direct PCR, in which $222(64.7 \%)$ samples were found to be positive for bovine hemoplasmas. Of these, 132 samples (38.5\%) were infected with Mw, 134 (39.1\%) were infected with $\mathrm{CMh}$ and $44(12.8 \%)$ were infected with both species (Table 2). The chi-square test performed on sampling location revealed significant differences in the prevalence of positive samples for total hemoplasma species and $\mathrm{CMh}$ between groups. The prevalence rate of $\mathrm{CMh}$ was higher for groups $\mathrm{C}$ and $\mathrm{D}$ (cattle from Tokachi distinct, Table 2).

Base on data obtained for all 343 cattle regarding living conditions and age, farmed cattle were significantly more susceptible to infection with hemoplasma $(P<0.001)$, particularly with $\mathrm{CMh}(P<0.001)$, compared with pastured cattle (Table 3). Furthermore, an association between hemoplasma infection prevalence and age was observed, with significant differences among groups (Table 3 ). Cattle 1 year of age and older had a higher risk of bovine hemoplasma infections than those less than 1 year of age. In particular, cattle that were 1-3 years of age showed the highest percentage of positive samples for bovine hemoplasma infections.

BLV status had been determined for 206 of the 343 cattle $(60.1 \%)$, of which $42(20.4 \%)$ were BLV positive in AGDI. No significant associations were found between BLV status and hemoplasma infections (Table 3).

CBCs were obtained for 291 blood samples. Hematological parameters were compared among the PCR-negative, Mwinfected, CMh-infected and coinfected groups. Mw-infected cattle showed significantly lower red blood cells (RBCs) and PCV levels and a higher mean corpuscular volume (MCV) than PCR-negative cattle (Table 4). CMh-infected cattle showed significantly lower RBCs, hemoglobin (HB), PCV and white blood cells (WBCs) and a higher MCV than
A. Direct PCR (using whole blood)

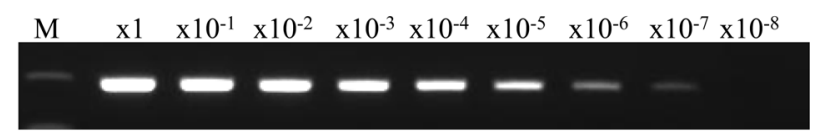

B. Standard PCR (using DNA)

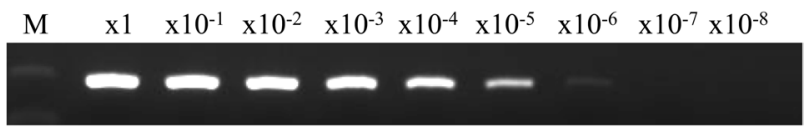

Fig. 1. PCR detection limits for hemoplasma DNA using a sequencespecific plasmid. (A) Direct PCR detected a positive band in a blood sample diluted to $10^{-7}$. (B) Standard PCR detected a positive band in a DNA solution diluted to $10^{-6}$. M: 100 bp ladder marker.

PCR-negative cattle (Table 4). Cattle coinfected with Mw and $\mathrm{CMh}$ showed significantly lower RBCs, HB and PCV levels and a higher MCV than PCR-negative cattle (Table 4). On the other hand, no significant hematological differences were found between Mw-infected, CMh-infected, and coinfected groups, except for WBC values (data not shown).

\section{DISCUSSION}

PCR amplification performed directly from whole blood can be useful in detecting blood organisms, as the method allows direct detection of pathogens in a blood sample [33]. However, whole blood contains various PCR inhibitors (e.g., lactoferrin, hemoglobin and heparin) that may interfere with direct amplification of DNA from cell lysates [3, 4, 31]. Recently, an improved PCR buffer was developed to neutralize these inhibitory substances in whole blood [2]. Direct PCR performed using this improved buffer has been shown to demonstrate superior sensitivity $[2,9]$. In the present study, we analyzed 49 samples by direct and standard PCR and found that the sensitivity of direct PCR was 10 -fold higher than standard PCR. The number of positive samples detected in direct and standard PCR was $35(71.4 \%)$ and $33(67.3 \%)$, respectively. The quality of all DNA samples was guaranteed, because the internal control gene was detected in all samples. There were the merits of the direct PCR method other than improvement of the sensitivity. Comparing the cost and operation time required to perform each method, direct PCR was $72.6 \%$ cheaper, and was approximately $2 \times$ faster than the standard PCR, which requires a DNA extraction protocol.

In the epidemiological survey, 222 of the 343 samples (64.7\%) were positive by direct PCR, which included 132 (38.5\%) positive samples for Mw, 134 (39.1\%) positive samples for $\mathrm{CMh}$ and $44(12.8 \%)$ positive samples for both species. Consistent with our findings, previous epidemiological studies have reported that $22.3-93.8 \%$ of cattle in Japan are infected with hemoplasma [5, 22, 28, 29].

Although pastured cattle are generally considered to have more exposure to blood-sucking arthropods that can transmit hemoplasmas [19], a significantly higher prevalence of 
Table 2. Numbers and percentages of cattle infected with hemoplasma detected by direct PCR in each sample group

\begin{tabular}{lcccccc}
\hline \multirow{2}{*}{ PCR-result } & \multicolumn{5}{c}{ No. of PCR-positive cattle (\%) } & \multirow{2}{*}{$P$ value } \\
\cline { 2 - 5 } & Group A ${ }^{\mathrm{a})}, \mathrm{n}=91$ & Group B $^{\mathrm{a}}, \mathrm{n}=46$ & Group C $^{\mathrm{a})}, \mathrm{n}=150$ & Group D $^{\mathrm{a})}, \mathrm{n}=56$ & Total, $\mathrm{n}=343$ & \\
\hline Total hemoplasmas & $45(49.5)$ & $24(52.2)$ & $113(75.3)$ & $40(71.4)$ & $222(64.7)$ & $<\mathbf{0 . 0 0 1}$ \\
Mw & $38(41.8)$ & $19(41.3)$ & $49(32.7)$ & $26(46.6)$ & $132(38.5)$ & 0.24 \\
CMh & $14(15.4)$ & $12(26.1)$ & $84(56.0)$ & $24(42.9)$ & $134(39.1)$ & $<\mathbf{0 . 0 0 1}$ \\
Mw + CMh & $7(7.7)$ & $7(15.2)$ & $20(13.3)$ & $10(17.9)$ & $44(12.8)$ & 0.30 \\
\hline
\end{tabular}

a) Group A: cattle pastured in Kushiro District. Group B: cattle fed in Kushiro District. Group C: cattle fed in a free stall barn in Tokachi District. Group D: cattle fed in a tie stall barn in Tokachi District.

b) $P$ values in bold are statistically significant $(P<0.05)$ in comparisons of groups A, B, C and D by using the $\chi^{2}$ test.

Table 3. Sample prevalence of bovine hemoplasma infections according to living conditions, age and BLV status

\begin{tabular}{|c|c|c|c|c|c|}
\hline \multirow{2}{*}{ Variable } & \multirow{2}{*}{ Total number } & \multicolumn{4}{|c|}{ PCR result (\%) } \\
\hline & & Mw positive & CMh positive & Dual positive & Total hemoplasma positive \\
\hline \multicolumn{6}{|c|}{ Living condition $(n=343)$} \\
\hline Pastureland & 91 & $38(41.8)$ & $14(15.4)$ & $7(7.7)$ & $45(49.5)$ \\
\hline Farm & 252 & $94(37.3)$ & $120(47.6)$ & $37(14.7)$ & $177(70.2)$ \\
\hline$P$ value ${ }^{\text {a) }}$ & & 0.45 & $<0.001$ & 0.09 & $<0.001$ \\
\hline \multicolumn{6}{|l|}{ Age $(n=343)$} \\
\hline$<1$ year & 128 & $35(27.3)$ & $10(7.8)$ & $3(2.3)$ & $42(32.8)$ \\
\hline $1 \leq$ years $<3$ & 105 & $57(54.3)$ & $70(66.7)$ & $30(28.6)$ & $97(92.4)$ \\
\hline $3 \leq$ years $<5$ & 55 & $19(34.5)$ & $31(56.4)$ & $4(7.3)$ & $46(83.6)$ \\
\hline$\geq 5$ years & 55 & $21(38.2)$ & $22(40.0)$ & $6(10.9)$ & $37(67.3)$ \\
\hline$P$ value ${ }^{\mathrm{b})}$ & & $<0.001$ & $<0.001$ & $<0.001$ & $<0.001$ \\
\hline \multicolumn{6}{|c|}{ BLV status $(n=206)$} \\
\hline BLV positive & 42 & $17(40.5)$ & $22(52.4)$ & $5(11.9)$ & $34(81.0)$ \\
\hline BLV negative & 164 & $58(35.4)$ & $86(52.4)$ & $25(15.2)$ & $119(72.6)$ \\
\hline$P$ value $^{\mathrm{c})}$ & & 0.54 & 0.99 & 0.58 & 0.27 \\
\hline
\end{tabular}

$P$ values in bold are statistically significant $(P<0.05)$.

a) $P$ value: comparison of pastureland and farm in each hemoplasma group by using the $\chi^{2}$ test.

b) $P$ value: comparison of each age groups in each hemoplasma group by using the $\chi^{2}$ test.

c) $P$ value: comparison of samples that were BLV positive and BLV negative in each hemoplasma group by using the $\chi^{2}$ test.

Table 4. Comparison of hematological findings between hemoplasma positive and negative groups

\begin{tabular}{lcccc}
\hline \multirow{2}{*}{$\begin{array}{c}\text { Parameters } \\
\text { Mean } \pm \mathrm{SD})\end{array}$} & \multicolumn{4}{c}{ PCR results } \\
\cline { 2 - 5 } MBC $\left(\times 10^{4} / \mu l\right)$ & $683.3 \pm 142.4^{* *}$ & $634.6 \pm 93.8^{* * *}$ & $649.4 \pm 106.6^{* *}$ & $747.0 \pm 180.6$ \\
$\mathrm{HB}(\mathrm{g} / \mathrm{d} l)$ & $10.4 \pm 1.1$ & $10.0 \pm 1.0^{* * *}$ & $10.2 \pm 1.2^{*}$ & $10.6 \pm 1.7$ \\
$\mathrm{HCT}(\%)$ & $29.6 \pm 3.2^{*}$ & $28.5 \pm 3.2^{* * *}$ & $29.3 \pm 3.5^{*}$ & $30.6 \pm 5.5$ \\
$\mathrm{MCV}(\mathrm{f} l)$ & $44.4 \pm 6.8^{*}$ & $45.3 \pm 3.8^{* * *}$ & $45.5 \pm 4.5^{* * *}$ & $42.4 \pm 7.7$ \\
$\mathrm{MCHC}(\mathrm{g} / \mathrm{d} l)$ & $35.1 \pm 1.2$ & $35.2 \pm 1.2$ & $35.0 \pm 1.0$ & $34.7 \pm 1.4$ \\
$\mathrm{WBC}\left(\times 10^{2} / \mu l\right)$ & $102.7 \pm 35.4$ & $86.3 \pm 29.3^{* * *}$ & $92.8 \pm 27.9$ & $101.8 \pm 35.4$ \\
\hline
\end{tabular}

The statistics of each hemoplasma-positive group were compared with those of the negative group.

* $P<0.05$; ** $P<0.01 ; * * * P<0.001$ (vs the negative group).

infections, especially with $\mathrm{CMh}$, was observed for farmed cattle. This could be attributed to the fact that most adult farmed cattle examined in the present study had previously been kept in a pasture. Veterinarians should note the fact that farmed cattle can be highly infected with hemoplasma.

Cattle that were 1-3 years of age had a higher prevalence of hemoplasma infections compared with other age groups. In Eastern Hokkaido, most 1-3-year-old cattle have been put out to pasture and have experienced their first pregnancy and delivery. The increased risk of contact with blood-sucking arthropods in the pasture, as well as pregnancy-induced immune depression, may have contributed to the higher prevalence of observed infections. Interestingly, detection of hemoplasma infections decreased progressively when cattle were 3 years of age or older. Hemoplasma infections have been reported more frequently in young dogs, which is likely due to a higher exposure rate of young active dogs to tick vectors [23]. However, there was a discrepancy in the rela- 
tion between age and occurrence of feline hemoplasmosis in past reports $[6,34]$; in cats, infections were most prevalent at less than 3 years of age [8]; on the other hand, hemoplasma infections were less frequently detected at 10 years of age or older [6]. It is unclear whether these observations in dogs and cats match those obtained in the present study because of the lifestyle differences among these animals. It is possible that older cattle have mature immunity, and thus bacterial pathogens can be removed from the blood more efficiently.

In cats, both feline immunodeficiency virus (FIV) and feline leukemia virus (FeLV) are regarded as important risk factors for feline hemoplasma infections $[6,7,14$, 30]. Although the reasons why feline retroviral infections are related to hemoplasma infections remain unclear, the routes of infection are thought to be the same [6]. Vertical transmission of BLV in cattle across the placenta or through colostrums has been previously reported [16]. Horizontal transmission of BLV has also been reported, which can occur with hematophagous insect bites or inappropriate medical treatment $[12,14]$. One report described the use of molecular techniques to show how hemoplasma could be transmitted vertically and horizontally in cattle [11]. In contrast with these findings, the present study showed no significant association between BLV infection and hemoplasma infections, suggesting that the major transmission route of hemoplasma could be distinct from that of BLV. More studies are needed to clarify the main routes of transmission for bovine hemoplasma.

Significantly lower RBCs and PCV levels, and a higher $\mathrm{MCV}$, were observed in the three groups of cattle infected with hemoplasma compared with the PCR-negative cattle, suggesting that the hemoplasma PCR-positive status was associated with anemia. On the other hand, no significant differences were found in HB levels between the Mw-infected and PCR-negative groups. Furthermore, no significant differences were found in MCHC levels. Although these differences were not significant, these were slightly higher tendencies for $\mathrm{CMh}$ - and coinfected groups to develop anemia relative to the $\mathrm{Mw}$-infected group. Our results showed that cattle with hemoplasma infections exhibit a decrease in anemia indicators (RBCs, HB and PCV) and an increase in MCV. This may be due to hemolytic anemia, which can result from hemoplasmas attaching to the surface of host erythrocytes, triggering production of secondary anti-erythrocyte autoantibodies [29]. The increase in MCV shows the appearance of immature red blood cells and is the index of regenerative anemia. Our previous study suggested a stronger effect of $\mathrm{CMh}$ infection on hematological parameters compared with $\mathrm{Mw}$ infection. However, we did not examine the pathogenicity of dual infection by the two bovine hemoplasma species [29]. An additive effect of dual infection by feline hemoplasma has been previously reported [35]. In the present study, the pathogenicity of dual infection with $\mathrm{Mw}$ and CMh was the same or slightly weaker compared with $\mathrm{CMh}$ infection alone. Nevertheless, the means of blood properties for all groups were within the reference ranges, and data widely overlapped. Thus, it is unclear whether the host animals were affected by abnormalities in blood proper- ties noted in this study. To date, few studies on the pathogenicity of chronic bovine hemoplasma infections have been performed, and thus further studies are necessary. This is the first report to describe the pathogenicity of dual infection with 2 species of bovine hemoplasma.

In conclusion, we found significant differences in the prevalence of bovine hemoplasma infections depending on sampling location, living conditions and age as risk factors. This observation supports the hypothesis that bovine hemoplasmas may transmitted by blood-sucking arthropods. Furthermore, compared with noninfected cattle, cattle infected with bovine hemoplasmas showed significantly lower RBCs, $\mathrm{HB}$ and PCV levels and a higher MCV. BLV-positive status was not significantly associated with hemoplasma infections. In the future, further epidemiological studies will be needed.

\section{REFERENCES}

1. Adler, S. and Ellenbogen, V. 1934. A note on two new blood parasites of cattle, eperythrozoon and bartonella. J. Comp. Pathol. Ther. 47: 219-221.

2. Alhassan, A., Iseki, H., Kim, C., Yokoyama, N. and Igarashi, I. 2007. Comparison of polymerase chain reaction methods for the detection of Theileria equi infection using whole blood compared with pre-extracted DNA samples as PCR templates. Trop. Anim. Health Prod. 39: 369-374. [Medline] [CrossRef]

3. Al-Soud, W. A. and Radstrom, P. 2001. Purification and characterization of PCR-inhibitory components in blood cells. J. Clin. Microbiol. 39: 485-493. [Medline] [CrossRef]

4. Burckhardt, J. 1994. Amplification of DNA from whole blood. PCR Methods Appl. 3: 239-243. [Medline] [CrossRef]

5. Fujihara, Y., Sasaoka, F., Suzuki, J., Watanabe, Y., Fujihara, M., Ooshita, K., Ano, H. and Harasawa, R. 2011. Prevalence of hemoplasma infection among cattle in the western part of Japan. J. Vet. Med. Sci. 73: 1653-1655. [Medline] [CrossRef]

6. Gentilini, F., Novacco, M., Turba, M. E., Willi, B., Bacci, M. L. and Hofmann-Lehmann, R. 2009. Use of combined conventional and real-time PCR to determine the epidemiology of feline haemoplasma infections in northern Italy. J. Feline Med. Surg. 11: 277-285. [Medline] [CrossRef]

7. George, J. W., Rideout, B. A., Griffey, S. M. and Pedersen, N. C. 2002. Effect of preexisting FeLV infection or FeLV and feline immunodeficiency virus coinfection on pathogenicity of the small variant of Haemobartonella felis in cats. Am. J. Vet. Res. 63: 1172-1178. [Medline] [CrossRef]

8. Grindem, C. B., Corbett, W. T. and Tomkins, M. T. 1990. Risk factors for Haemobartonella felis infection in cats. J. Am. Vet. Med. Assoc. 196: 96-99. [Medline]

9. Higuchi, H., Iwano, H., Kawai, K., Ohta, T., Obayashi, T., Hirose, K., Ito, N., Yokota, H., Tamura, Y. and Nagahata, H. 2011. A simplified PCR assay for fast and easy mycoplasma mastitis screening in dairy cattle. J. Vet. Sci. 12: 191-193. [Medline] [CrossRef]

10. Hoelzle, K., Winkler, M., Kramer, M. M., Wittenbrink, M. M., Dieckmann, S. M. and Hoelzle, L. E. 2011. Detection of Candidatus Mycoplasma haemobos in cattle with anaemia. Vet. J. 187: 408-410. [Medline] [CrossRef]

11. Hornok, S., Micsutka, A., Meli, M. L., Lutz, H. and HofmannLehmann, R. 2011. Molecular investigation of transplacental and vector-borne transmission of bovine haemoplasmas. Vet. Microbiol. 152: 411-414. [Medline] [CrossRef]

12. Inoue, Emi., Matsumura, K., Maekawa, K., Nagatsuka, K., 
Nobuta, M., Hirata, M., Minagawa, A., Osawa, Y. and Okazaki, K. 2011. Genetic heterogeneity among bovine leukemia viruses in Japan and their relationship to leukemogenicity. Arch. Virol. 156: 1137-1141. [Medline] [CrossRef]

13. Jensen, W. A., Lappin, M. R., Kamkar, S. and Reagen, W. J. 2001. Use of a polymerase chain reaction assay to detect and differentiate two strains of Haemobartonella felis in naturally infected cats. Am. J. Vet. Res. 62: 604-608. [Medline] [CrossRef]

14. Kobayashi, S., Tsutsui, T., Yamamoto, T., Hayama, Y., Kameyama, K., Konishi, M. and Murakami, K. 2010. Risk factors associated with within-herd transmission of bovine leukemia virus on dairy farms in Japan. BMC Vet. Res. 6: article no. 1. [Medline] [CrossRef]

15. Macieira, D. B., de Menezes, R. C., Damico, C. B., Almosny, N. R., McLane, H. L., Daggy, J. K. and Messick, J. B. 2008. Prevalence and risk factors for hemoplasmas in domestic cats naturally infected with feline immunodeficiency virus and/or feline leukemia virus in Rio de Janeiro-Brazil. J. Feline Med. Surg. 10: 120-129. [Medline] [CrossRef]

16. Martin, D., Arjona, A., Soto, I., Barquero, N., Viana, M. and Gómez-Lucía, E. 2001. Comparative study of PCR as a direct assay and ELISA and AGID as indirect assays for the detection of bovine leukaemia virus. J. Vet. Med. B Infect. Dis. Vet. Public Health 48: 97-106. [Medline] [CrossRef]

17. McAuliffe, L., Lawes, J., Bell, S., Barlow, A., Ayling, R. and Nicholas, R. 2006. The detection of Mycoplasma (formerly Eperythrozoon) wenyonii by $16 \mathrm{~S}$ rRNA PCR and denaturing gradient gel electrophoresis. Vet. Microbiol. 117: 292-296. [Medline] [CrossRef]

18. Meli, M. L., Willi, B., Dreher, U. M., Cattori, V., KnubbenSchweizer, G., Nuss, K., Braun, U., Lutz, H. and HofmannLehmann, R. 2010. Identification, molecular characterization, and occurrence of two bovine hemoplasma species in Swiss cattle and development of real-time TaqMan quantitative PCR assays for diagnosis of bovine hemoplasma infections. J. Clin. Microbiol. 48: 3563-3568. [Medline] [CrossRef]

19. Messick, J. B. 2004. Hemotrophic mycoplasmas (hemoplasmas): a review and new insights into pathogenic potential. Vet. Clin. Pathol. 33: 2-13. [Medline] [CrossRef]

20. Neimark, H. and Kocan, K. M. 1997. The cell wall-less rickettsia Eperythrozoon wenyonii is a Mycoplasma. FEMS Microbiol. Lett. 156: 287-291. [Medline] [CrossRef]

21. Neimark, H., Johansson, K. E., Rikihisa, Y. and Tully, J. G. 2001. Proposal to transfer some members of the genera Haemobartonella and Eperythrozoon to the genus Mycoplasma with descriptions of 'Candidatus Mycoplasma haemofelis', 'Candidatus Mycoplasma haemomuris', 'Candidatus Mycoplasma haemosuis' and 'Candidatus Mycoplasma wenyonii'. Int. J. Syst. Evol. Microbiol. 51: 891-899. [CrossRef]

22. Nishizawa, I., Sato, M., Fujihara, M., Sato, S. and Harasawa, R. 2010. Differential detection of hemotropic Mycoplasma species in cattle by melting curve analysis of PCR products. J. Vet. Med. Sci. 72: 77-79. [Medline] [CrossRef]

23. Novacco, M., Meli, M. L., Gentilini, F., Marsilio, F., Ceci, C., Pennisi, M. G., Lombardo, G., Lloret, A., Santos, L., Carrapiço, T., Willi, B., Wolf, G., Lutz, H. and Hofmann-Lehmann, R. 2010. Prevalence and geographical distribution of canine hemotropic mycoplasma infections in Mediterranean countries and analysis of risk factors for infection. Vet. Microbiol. 142:
276-284. [Medline] [CrossRef]

24. Peters, I. R., Helps, C. R., Willi, B., Hofmann-Lehmann, R. and Tasker, S. 2008. The prevalence of three species of feline haemoplasmas in samples submitted to a diagnostic service as determined by three novel real-time duplex PCR assays. Vet. Microbiol. 126: 142-150. [Medline] [CrossRef]

25. Smith, J. A., Thrall, M. A., Smith, J. L., Salman, M. D., Ching, S. V. and Collins, J. K. 1990. Eperythrozoon wenyonii infection in dairy cattle. J. Am. Vet. Med. Assoc. 196: 1244-1250. [Medline]

26. Su, Q. L., Song, H. Q., Lin, R. Q., Yuan, Z. G., Yang, J. F., Zhao, G. H., Huang, W. Y. and Zhu, X. Q. 2010. The detection of "Candidatus Mycoplasma haemobos" in cattle and buffalo in China. Trop. Anim. Health Prod. 42: 1805-1808. [Medline] [CrossRef]

27. Sykes, J. E., Drazenovich, N. L., Ball, L. M. and Leutenegger, C. M. 2007. Use of conventional and real-time polymerase chain reaction to determine the epidemiology of hemoplasma infections in anemic and nonanemic cats. J. Vet. Intern. Med. 21: 685-693. [Medline] [CrossRef]

28. Tagawa, M., Matsumoto, K. and Inokuma, H. 2008. Molecular detection of Mycoplasma wenyonii and 'Candidatus Mycoplasma haemobos' in cattle in Hokkaido, Japan. Vet. Microbiol. 132: 177-180. [Medline] [CrossRef]

29. Tagawa, M., Matsumoto, K., Yokoyama, N. and Inokuma, H. 2010. Comparison of two hemoplasma species on hematological parameters in cattle. J. Vet. Med. Sci. 72: 113-115. [Medline] [CrossRef]

30. Tanahara, M., Miyamoto, S., Nishio, T., Yoshii, Y., Sakuma, M., Sakata, Y., Nishigaki, K., Tsujimoto, H., Setoguchi, A. and Endo, Y. 2010. An epidemiological survey of feline hemoplasma infection in Japan. J. Vet. Med. Sci. 72: 1575-1581. [Medline] [CrossRef]

31. Watanabe, M., Hisasue, M., Souma, T., Namikawa, K., Ikehara, S., Tsuchiya, R. and Yamada, T. 2007. Assessment of sensitivity to canine Babesia gibsoni infection by a direct PCR method using canine whole blood samples. J. Anim. Clin. Med. 16: 87-91 (in Japanese. with English Abstract).

32. Watanabe, M., Hisasue, M., Soma, T., Namikawa, K., Segawa, K. and Tsuchiya, R. 2011. Detection of new hemoplasma 'Candidatus Mycoplasma turicensis' infection in domestic cats in Japan. J. Jpn. Vet. Med. Assoc. 64: 150-153 (in Japanese. with English Abstract).

33. Watanabe, M., Hisasue, M., Souma, T., Ohshiro, S., Yamada, T. and Tsuchiya, R. 2008. Molecular detection of Mycoplasma haemofelis and 'Candidatus Mycoplasma haemominutum' Infection in cats by direct PCR using whole blood without DNA extraction. J. Vet. Med. Sci. 70: 1095-1099. [Medline] [CrossRef]

34. Willi, B., Boretti, F. S., Baumgartner, C., Tasker, S., Wenger, B., Cattori, V., Meli, M. L., Reusch, C. E., Lutz, H. and HofmannLehmann, R. 2006. Prevalence, risk factor analysis, and followup of infections caused by three feline hemoplasma species in cats in Switzerland. J. Clin. Microbiol. 44: 961-969. [Medline] [CrossRef]

35. Willi, B., Tasker, S., Boretti, F. S., Doherr, M. G., Cattori, V., Meli, M. L., Lobetti, R. G., Malik, R., Reusch, C. E., Lutz, H. and Hofmann-Lehmann, R. 2006. Phylogenetic analysis of "Candidatus Mycoplasma turicensis" isolates from pet cats in the United Kingdom, Australia, and South Africa, with analysis of risk factors for infection. J. Clin. Microbiol. 44: 4430-4435. [Medline] [CrossRef] 